\title{
Distribution of structure and lignin within growth rings of Norway
}

\section{spruce}

\section{Journal Article}

\section{Author(s):}

Lanvermann, Christian; Evans, Robert; Schmitt Uwe; Hering, Stefan; Niemz, Peter

Publication date:

2013-05

Permanent link:

https://doi.org/10.3929/ethz-b-000065872

\section{Rights / license:}

In Copyright - Non-Commercial Use Permitted

\section{Originally published in:}

Wood Science and Technology 47(3), https://doi.org/10.1007/s00226-013-0529-8 


\title{
Distribution of structure and lignin within growth rings of Norway spruce
}

\author{
Christian Lanvermann - Robert Evans • \\ Uwe Schmitt $\cdot$ Stefan Hering $\cdot$ Peter Niemz
}

Received: 30 March 2012/Published online: 22 February 2013

(C) Springer-Verlag Berlin Heidelberg 2013

\begin{abstract}
A radial core from a Norway spruce (Picea abies (L.) Karst.) estimated to be about 107 years old was cut from a board and was analyzed for density and microfibril angle (MFA). Furthermore, cell geometry, wall thickness and lignin distribution were analyzed on three selected growth rings in detail. Intra-ring differences in the density profiles are also true for cell wall thicknesses as well as radial and tangential lumen diameters. A higher MFA was found for earlywood with a slow decrease toward the latewood region. The lignin was found to remain rather constant throughout the growth rings, which suggests a constant chemical composition of the cell wall material within the growth ring. From the recorded datasets on a cellular level, it can be concluded that the main adaptation regarding structureproperty relationships toward the optimization of water transport and mechanical stability is mainly achieved at the cell level.
\end{abstract}

C. Lanvermann $(\bowtie) \cdot$ P. Niemz

Institute for Building Materials, Woodphysics, ETH Zurich, Schafmattstrasse 6,

8093 Zurich, Switzerland

e-mail: lanvermannchr@ethz.ch

R. Evans

CSIRO Materials Science and Engineering, Normansby Road, Clayton, VIC 3168, Australia

U. Schmitt

Thünen Institute for Wood Technology and Wood Biology, Leuschnerstrasse 91,

21031 Hamburg, Germany

S. Hering

Institute for Building Materials, Computational Physics for Building Materials, ETH Zurich, Schafmattstrasse 6, 8093 Zurich, Switzerland 


\section{Introduction}

Wood is a macroscopically strictly organized hierarchical natural material. Sapwood and heartwood maintain this structure at the mesoscopic level, with a growth ring structure down to the microscopic level and with a layered cell wall architecture and a distinct organization of the constituent substances within each wall layer (e.g., Salmén 2004; Burgert 2006). Numerous studies have identified the main influencing factors on the physical properties such as density, wall thickness, microfibril orientation within cell wall layers and their chemical composition (e.g., Fengel and Wegener 1984; Bodig and Jayne 1993; Niemz 1993). Those individual studies, however, were mainly focused on a single factor only. Since for woody plants, a high intra-individual as well as inter-individual variability of the structure is well known, only the investigation of several parameters in one wood sample can serve to shed light on specific structure-property relationships.

A review of the investigations into tracheid cell geometry and microfibril angle (MFA) in Norway spruce can be found in Brändström (2001). Earlywood is characterized by wide lumen and thin cell walls that gradually increase toward the end of the growth ring (Fengel and Stoll 1973). The terminal latewood cell often shows thinner cell walls than the preceding cell. Wood formation is driven by several factors, including altitude (Gindl et al. 2001), light intensity (Jenkins 1975) and precipitation (Lassen and Okkonen 1969). These influences also affect growth ring width, latewood percentage and wood density (e.g. Fritts 1976; Oleksyn and Fritts 1991). This generally leads to a considerable variation of properties within a given species (Zobel and Van Buijtenen 1989). However, often only mean values are given without differentiation between the radial and tangential directions. Eder et al. (2009) reported the average cell wall area and lumen dimension in the radial direction on 13 consecutive radial slices. However, a more complete description of cell geometry within single growth rings can scarcely be found in the literature. Derome et al. (2011b) studied relations between cell geometry and vapor permeability across a growth ring. In this study, ESEM images of the radial/ tangential surface containing one complete growth ring were used to manually measure the lumen dimensions and cell wall thicknesses in both the radial and the tangential directions.

X-ray techniques are commonly used to determine density distribution. Density profiles are widely used in dendrochronology in combination with growth ring width as the preferred approach to assess the impact of silvicultural management and environmental conditions as well as other site specific conditions, such as elevation (e.g. Splechtna et al. 2000; Kienast et al. 1987).

A comprehensive review of the MFA, its measurement techniques and relationships can be found in Donaldson (2008). According to this review, a slow decline of MFA was observed from earlywood to latewood, whereby a distinct decrease sometimes occurred at the terminal side of a growth ring. However, Lichtenegger et al. (1999) found significantly lower MFAs for earlywood than for latewood.

Lignin is often referred to as the cement-like matrix in which cellulose fibrils and hemicelluloses are embedded. In contrast to concrete, the compressive strength of 
lignin is relatively low. Therefore, lignin rich layers of the wood structure, such as the compound middle lamella, exhibit lower Young's modulus of elasticity (Gindl et al. 2004; Wimmer et al. 1997; Wimmer and Lucas 1997).

While the influences on tracheid morphology seem to follow clear trends, the chemical intra-incremental variation is unclear and sometimes contradictory. For several coniferous species, Wilson and Wellwood (1965) found a higher lignin content for earlywood than for latewood. This decrease toward latewood was found by several other studies for Picea abies (Gindl et al. 2001), Pinus nigra (Gindl 2001a) and Picea mariana (Fergus et al. 1969). Furthermore, this decrease is reflected in the positive correlation between radial cell diameter and lignin content for Pinus nigra (Gindl 2001a). Additionally, Fukazawa and Imagawa (1981) found a rather constant lignin content for earlywood and a steep increase for latewood in Abies sachalinensis. The same influences that have been identified for cell morphology, ring width and density, namely temperature and elevation, are reflected in lignin concentration (Gindl et al. 2000, 2001; Gindl and Grabner 2000; Gindl 2001b).

The cell geometry, cell wall thicknesses, density and chemical composition, and thus their interrelationships not only reveal natural strategies for optimization, but can also be used to synthesize the material behavior in numerical models. Nowadays, various computational approaches exist to calculate material, such as density and permeability (e.g. Perré and Badel 2003), and mechanical properties (Hofstetter et al. 2005; Badel and Perré 2007; Qing and Mishnaevsky 2009). Hereby, either mean values for the individual factors are used or small cell structures are digitized from microscopic images (e.g., Derome et al. 2011a). However, several of these factors have to be adopted from literature. Therefore, these studies could benefit from one consistent dataset.

The aim of this study on Norway spruce (Picea abies (L.) Karst.) wood is to analyze the data on density, MFA, cell geometry, cell wall thicknesses and cellular lignin contents along a radial gradient from pith to bark in detail. This data will serve as input parameters for structural modeling of moisture-induced deformations as well as the underlying basis for the explanation of their variability within growth rings in the ongoing project.

In the current study, the obtained results are discussed in the context of structurefunction relationships as well as in the context of modeling wood properties.

\section{Material}

For the current investigations, a board from a stem of Norway spruce (Picea abies (L.) Karst.) originating from Dielsdorf, Switzerland, was used. From this board, a core sample of clear wood with a parallel alignment of the tracheids in the longitudinal direction was cut approximately $1 \mathrm{~m}$ from the stems base. The core sample, although it did not contain the pith, consisted of 104 growth rings, with the innermost not having more than 3-4 growth rings from the pith. The measurements follow a twofold path: first, density and MFA profiles were generated spanning the whole cross section, and secondly, three individual growth rings were chosen for 
cell geometry and lignin measurements in the RT-plane. The growth rings selected for the latter investigations included one that was close to the cambium, one from the intermediate region and one close to the pith, namely growth ring numbers 2 (width: $2.57 \mathrm{~mm}$ ), 64 (width: $3.15 \mathrm{~mm}$ ) and 94 (width: $5.55 \mathrm{~mm}$ ). It should be noted that the growth rings were numbered from the cambium toward the pith, due to the absence of pith in the original board.

Due to different sample dimensions necessitating different applied measurement techniques, special care had to be taken during sample preparation. Therefore, the core sample cut from the board was split into two adjacent samples of approximately $20 \times 20 \times 370 \mathrm{~mm}^{3}$ (tangential $\times$ longitudinal $\times$ radial direction) consisting of the same growth rings. One of those twin samples was used for density and MFA profiles, while the other one was used for cell geometry and lignin measurements. On the latter sample, the growth rings of particular interest to this investigation were cut free with a chisel. These samples were again split into two adjacent samples, one for cell geometry and one for lignin measurements.

\section{Methods}

Density and microfibril angle

The automated microstructure analysis device SilviScan ${ }^{\circledR}$ was used to measure density (imaging X-ray densitometry) and MFA (imaging X-ray diffractometry) as initially described by Evans (1994) and Evans et al. (1999), although methods have continued to evolve since those publications. Each data point represents the integral value over the sample thickness in the tangential direction (parallel to the growth ring boundaries). Density images were obtained with $6-\mu \mathrm{m}$ pixel size and averaged over $25-\mu \mathrm{m}$ radial intervals to form a radial density profile. MFA measurements were made at $100-\mu \mathrm{m}$ radial intervals and placed on the same $25-\mu \mathrm{m}$ scale as the density profile. The measurements were carried out at ambient conditions, which are not further specified but should be close to normal conditions.

\section{Cell geometry}

Images at 1,000× magnification were taken in overlapping tiles using a fieldemission scanning electron microscope (FEI Electron Microscopes, USA) then joined together to show a complete growth ring. The samples were first moistened with deionized water and cut with a scalpel to maintain a clean surface. Since the images were recorded under vacuum conditions, the air is considered almost dry.

The following dimensions were obtained manually from the images: cell wall thicknesses and lumen dimensions in both the radial and the tangential directions (Fig. 1). The data were then assigned cell-wise with each cell's position defined over the radial position of its center of gravity within the growth ring.

Radial rows near the tracheid tips were excluded, as were cell walls containing preparation artifacts and pits. Furthermore, the thickness measurements were made at positions uninfluenced by cell corners. The high magnification and resolution of 

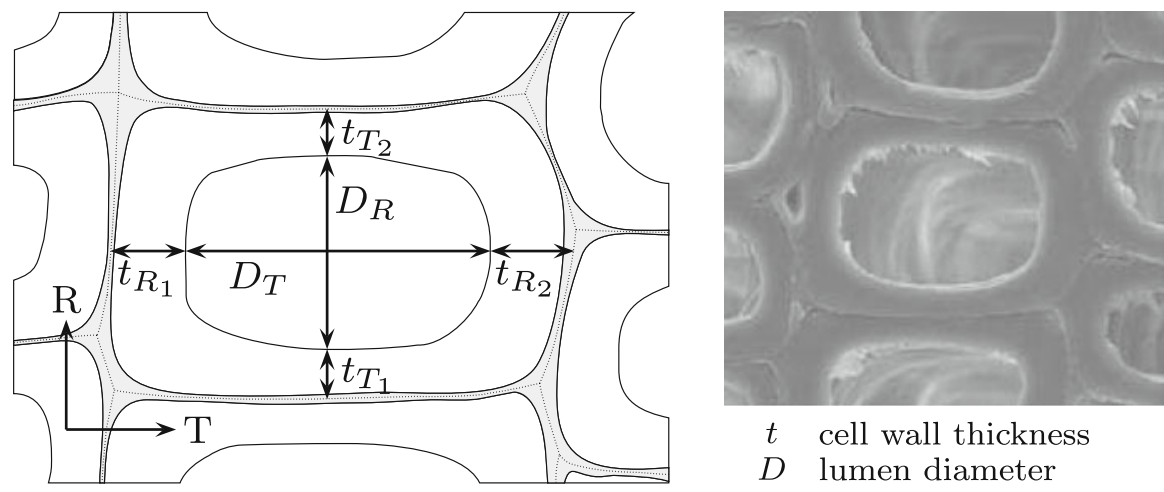

Fig. 1 Schematic of measured cell wall thicknesses (tangential and radial cell wall thickness $t_{\mathrm{T}}$ and $t_{\mathrm{R}}$ and tangential and radial lumen diameter $\left(D_{\mathrm{T}}\right.$ and $\left.D_{\mathrm{R}}\right)$ ). Center of CPL is presented as dashed line. Representative electron-microscopic image taken at 1,000× magnification (right)

the images $(0.14 \mu \mathrm{m}$ per pixel) allowed the cell wall thickness to be measured from the compound middle lamella (CPL) to the lumen with reasonable precision as shown in Fig. 1.

\section{Topochemical lignin distribution}

For the determination of the topochemical lignin content, a universal microspectrometer (UMSP 80, Carl Zeiss, Germany) with a pixel size of $0.25 \times 0.25 \mu \mathrm{m}^{2}$ was applied.

Therefore, the samples were embedded in Spurr's epoxy resin and cut to $1 \mu \mathrm{m}$ thick slices using an Ultra-microtome (Co. Reichert-Jung, Germany). The crosssectional samples contained one complete growth ring.

The slices were placed on quartz microscope slides, immersed in glycerin and covered with a quartz microscope cover slip before being placed under the oilimmersion lens. The measurements were carried out at a wavelength of $280 \mathrm{~nm}$, known as the absorbance maximum of softwood lignin (Scott et al. 1969). Field scans were made of the tangential cell walls. From the original datasets, the cell corner regions were removed, therefore, only giving datasets that contained straight cell wall material. These data were smoothed slightly to remove inevitable noise, and the mean absorbance per wall area was computed. To assign the measurement data to a specific position within the growth ring, light microscopic images were acquired and the radial position of the compound middle lamella was recorded.

\section{Results}

The results obtained with SilviScan ${ }^{\circledR}$, namely the radial density and MFA profile of the core sample, are presented in Fig. 1. The growth rings of special interest on which cell geometry and lignin content have also been determined are highlighted 
with gray rectangles. In order to identify general trends, a moving average of 1,000 adjacent data points was added to both density and MFA plots (Fig. 2).

Density readings show a more or less constant average throughout the core section with only slight maxima (position around 215 and $280 \mathrm{~mm}$ ), which coincide with narrow growth rings, whereas the mean MFA shows a higher variability.

On the other hand, in growth rings with a reduced density, in the MFA, local maxima (radial positions 67 and $240 \mathrm{~mm}$ ) appear. The overall mean density calculated from the profile is $352 \mathrm{~kg} \mathrm{~m}^{-3}$ (Table 1), corresponding to the lower end of the density range found in literature (e.g. Wagenführ 2000). In view of the high variability of MFA and the dependence on measurement techniques, the overall mean value of $15.0^{\circ}$ (Table 1) fits well with values reported in literature (Brändström 2001).

The close-up distributions of density, MFA, cell geometry and corresponding cell wall thickness for growth ring numbers 2, 64 and 94 are displayed in Fig. 3. To allow for comparability of the data according to the different growth ring widths for three growth rings, the ordinate is displayed as the normalized growth ring position where 0 denotes the earlywood and 1 the latewood boundary. Furthermore, the parameters of the fit functions for the individual properties are given in Table 2.

For all three growth rings, the density slightly increased in the earlywood regions and then sharply increased within the latewood until the end of the growth ring. The mean values, given in Table 1 , range from 278 to $344 \mathrm{~kg} \mathrm{~m}^{-3}$ for earlywood and from 596 to $727 \mathrm{~kg} \mathrm{~m}^{-3}$ for latewood portions.
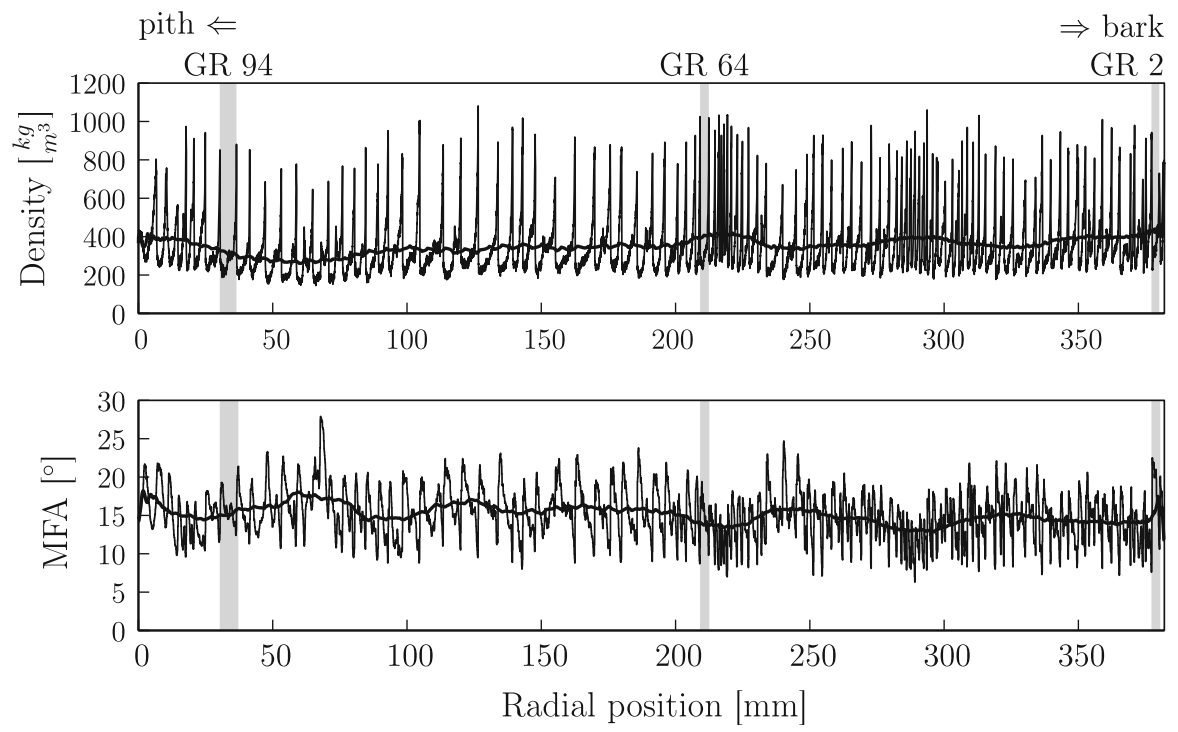

Fig. 2 Density, MFA and corresponding moving average (1,000 adjacent data points) of the whole cross section. Growth rings of special interest, on which cell geometry and lignin distribution measurements were performed, are marked with gray rectangles. Please note that growth ring numbering starts from the bark due to the absence of pith in the investigated core sample 
Table 1 Mean density, MFA and cell geometry values (tangential cell wall thickness $t_{\mathrm{T}}$, radial cell wall thickness $t_{\mathrm{R}}$, radial and tangential lumen diameter $D_{\mathrm{R}}, D_{\mathrm{T}}$ ) for individual growth rings and earlywood (EW) and latewood (LW)

\begin{tabular}{|c|c|c|c|c|c|c|c|}
\hline & \multirow{3}{*}{ Overall } & \multicolumn{6}{|c|}{ Ring number from bark } \\
\hline & & \multicolumn{2}{|l|}{ GR2 } & \multicolumn{2}{|l|}{ GR64 } & \multicolumn{2}{|l|}{ GR94 } \\
\hline & & EW & LW & EW & LW & EW & LW \\
\hline Density $\left(\mathrm{kg} \mathrm{m}^{-3}\right)$ & 352 & 344 & 596 & 311 & 727 & 278 & 631 \\
\hline $\operatorname{CoV}(\%)$ & 43.8 & 19.6 & 12.8 & 21.0 & 22.2 & 22.2 & 20.8 \\
\hline $\operatorname{MFA}\left({ }^{\circ}\right)$ & 15.0 & 19.6 & 12.2 & 15.4 & 10.8 & 15.9 & 13.4 \\
\hline $\operatorname{CoV}(\%)$ & 21.5 & 12.1 & 9.7 & 12.1 & 8.2 & 10.0 & 10.9 \\
\hline$t_{\mathrm{T}}\left(10^{-6} \mathrm{~m}\right)$ & - & 2.2 & 3.8 & 1.6 & 3.7 & 1.7 & 2.8 \\
\hline $\operatorname{CoV}(\%)$ & & 28.8 & 24.0 & 37.0 & 21.7 & 37.3 & 24.2 \\
\hline$t_{\mathrm{R}}\left(10^{-6} \mathrm{~m}\right)$ & - & 2.3 & 5.7 & 2.1 & 5.8 & 1.5 & 3.8 \\
\hline $\operatorname{CoV}(\%)$ & & 39.5 & 29.5 & 33.9 & 29.3 & 31.5 & 26.1 \\
\hline$D_{\mathrm{R}}\left(10^{-6} \mathrm{~m}\right)$ & - & 37.6 & 16.2 & 37.5 & 14.5 & 34.1 & 15.1 \\
\hline $\operatorname{CoV}(\%)$ & & 18.6 & 49.3 & 18.9 & 54.7 & 19.9 & 38.5 \\
\hline$D_{\mathrm{T}}\left(10^{-6} \mathrm{~m}\right)$ & - & 38.4 & 28.6 & 37.7 & 24.3 & 25.4 & 16.0 \\
\hline $\operatorname{CoV}(\%)$ & & 15.1 & 20.6 & 11.8 & 24.2 & 18.9 & 26.5 \\
\hline $\mathrm{A}_{280}(-)$ & - & 0.14 & 0.18 & 0.22 & 0.25 & 0.13 & 0.20 \\
\hline $\operatorname{CoV}(\%)$ & & 24.8 & 20.4 & 18.7 & 19.4 & 31.2 & 21.0 \\
\hline
\end{tabular}

The latewood fractions were calculated according to $\left(2 \times t_{\mathrm{T}}\right) / \mathrm{DR} \geq 0.25$ (Mork's index). The coefficient of variation $(\mathrm{CoV})$ is given in italics

The MFA was found to decrease steadily from earlywood to latewood with mean values from $14.6^{\circ}$ to $22.5^{\circ}$ for earlywood and $11.2^{\circ}-12.4^{\circ}$ for latewood for all three growth rings.

The cell wall thicknesses in the radial and tangential directions showed similar overall behavior of the growth rings. Wall thickness remained almost constant in earlywood and then sharply increased in the latewood region where they reached their maximum. A clear difference can be seen in the maximum thicknesses. In earlywood, the mean radial and tangential wall thicknesses were similar (1.6-2.2 $\mu \mathrm{m}$ and $1.5-2.3 \mu \mathrm{m}$, respectively). In latewood, the radial cell walls $(3.8-5.8 \mu \mathrm{m})$ were about $45 \%$ thicker than the tangential walls $(2.8-3.8 \mu \mathrm{m})$. Furthermore, the tangential cell wall thickness data show a greater scatter of the data.

The same overall behavior can be found for the radial and tangential lumen diameter for the three growth rings. While both remain fairly constant in earlywood, in latewood the radial lumen diameter drops to almost zero. The tangential lumen diameter also decreases, but not as sharply as the radial lumen diameter. This is reflected in the mean values for the lumen diameter: $D_{\mathrm{T}}$ in earlywood $(25.4-38.4 \mu \mathrm{m})$ is almost equal to $D_{\mathrm{R}}(34.1-37.6 \mu \mathrm{m})$, whereas in latewood, $D_{\mathrm{T}}$ $(16.0-28.6 \mu \mathrm{m})$ is about $50 \%$ higher than $D_{\mathrm{R}}(14.5-16.2 \mu \mathrm{m})$.

In the present investigation, the cell wall thicknesses for both, the radial and the tangential walls, were measured from the CPL's center to the individual lumen 

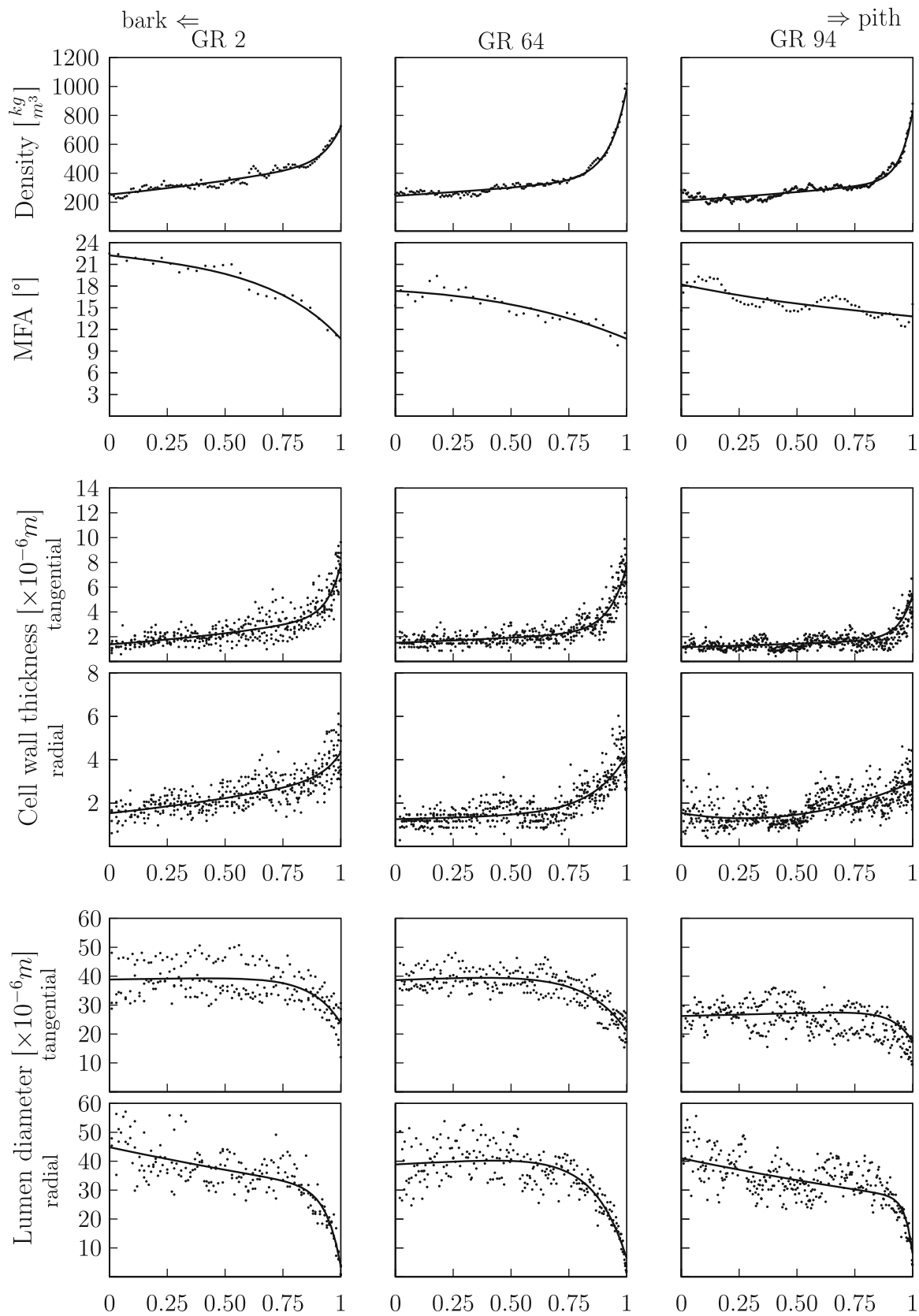

Normalized growth ring position [-]

Fig. 3 Density, MFA, cell geometry (cell wall thickness and lumen diameter in the radial and tangential distributions) over the growth ring calculated from tangential cell walls for growth rings 2, 64 and 94 and their corresponding fit functions. Normalized growth ring position 0 refers to earlywood boundary, 1 to latewood boundary 
Table 2 Parameters of the fit function for the three growth rings and individual properties

\begin{tabular}{|c|c|c|c|c|c|}
\hline \multirow[t]{2}{*}{ Growth ring } & \multirow[t]{2}{*}{ Property } & \multicolumn{4}{|l|}{ Parameter } \\
\hline & & $a$ & $b$ & $c$ & $d$ \\
\hline \multirow[t]{7}{*}{2} & Density & $2.527 \mathrm{E}+02$ & $6.478 \mathrm{E}-01$ & $2.592 \mathrm{E}-04$ & $1.378 \mathrm{E}+01$ \\
\hline & MFA & $2.259 \mathrm{E}+01$ & $-9.819 \mathrm{E}-02$ & $-3.467 \mathrm{E}-01$ & $3.350 \mathrm{E}+00$ \\
\hline & $t_{\mathrm{T}}$ & $1.377 \mathrm{E}+00$ & $1.007 \mathrm{E}+00$ & $1.347 \mathrm{E}-07$ & $1.726 \mathrm{E}+01$ \\
\hline & $t_{\mathrm{R}}$ & $1.534 \mathrm{E}+00$ & $7.475 \mathrm{E}-01$ & $2.281 \mathrm{E}-06$ & $1.313 \mathrm{E}+01$ \\
\hline & $D_{\mathrm{R}}$ & $-2.737 \mathrm{E}-06$ & $1.615 \mathrm{E}+01$ & $4.485 \mathrm{E}+01$ & $-3.846 \mathrm{E}-01$ \\
\hline & $D_{\mathrm{T}}$ & $-6.135 \mathrm{E}-03$ & $7.918 \mathrm{E}+00$ & $3.886 \mathrm{E}+01$ & $3.432 \mathrm{E}-02$ \\
\hline & Absorbance & $-5.000 \mathrm{E}-04$ & $3.490 \mathrm{E}+00$ & $1.089 \mathrm{E}-01$ & $6.235 \mathrm{E}-01$ \\
\hline \multirow[t]{7}{*}{64} & Density & $2.435 \mathrm{E}+02$ & $4.185 \mathrm{E}-01$ & $1.378 \mathrm{E}-03$ & $1.304 \mathrm{E}+01$ \\
\hline & MFA & $-1.010 \mathrm{E}+05$ & $5.454 \mathrm{E}-01$ & $1.010 \mathrm{E}+05$ & $5.453 \mathrm{E}-01$ \\
\hline & $t_{\mathrm{T}}$ & $1.506 \mathrm{E}+00$ & $4.805 \mathrm{E}-01$ & $9.337 \mathrm{E}-06$ & $1.328 \mathrm{E}+01$ \\
\hline & $t_{\mathrm{R}}$ & $1.255 \mathrm{E}+00$ & $1.901 \mathrm{E}-01$ & $3.312 \mathrm{E}-03$ & $6.720 \mathrm{E}+00$ \\
\hline & $D_{\mathrm{R}}$ & $3.891 \mathrm{E}+01$ & $1.149 \mathrm{E}-01$ & $-3.351 \mathrm{E}-02$ & $7.036 \mathrm{E}+00$ \\
\hline & $D_{\mathrm{T}}$ & $-7.746 \mathrm{E}-02$ & $5.639 \mathrm{E}+00$ & $3.871 \mathrm{E}+01$ & $9.324 \mathrm{E}-02$ \\
\hline & Absorbance & $2.502 \mathrm{E}-01$ & $-3.174 \mathrm{E}-01$ & $6.362 \mathrm{E}-12$ & $2.379 \mathrm{E}+01$ \\
\hline \multirow[t]{7}{*}{94} & Density & $2.096 \mathrm{E}+02$ & $5.101 \mathrm{E}-01$ & $3.224 \mathrm{E}-06$ & $1.886 \mathrm{E}+01$ \\
\hline & MFA & $1.683 \mathrm{E}+01$ & $-2.067 \mathrm{E}-01$ & $1.407 \mathrm{E}+00$ & $-2.564 \mathrm{E}+00$ \\
\hline & $t_{\mathrm{T}}$ & $1.148 \mathrm{E}+00$ & $4.525 \mathrm{E}-01$ & $2.253 \mathrm{E}-07$ & $1.661 \mathrm{E}+01$ \\
\hline & $t_{\mathrm{R}}$ & $1.040 \mathrm{E}+00$ & $-2.839 \mathrm{E}+00$ & $5.082 \mathrm{E}-01$ & $1.756 \mathrm{E}+00$ \\
\hline & $D_{\mathrm{R}}$ & $-1.980 \mathrm{E}-13$ & $3.231 \mathrm{E}+01$ & $4.101 \mathrm{E}+01$ & $-4.082 \mathrm{E}-01$ \\
\hline & $D_{\mathrm{T}}$ & $-4.376 \mathrm{E}-05$ & $1.247 \mathrm{E}+01$ & $2.621 \mathrm{E}+01$ & $7.616 \mathrm{E}-02$ \\
\hline & Absorbance & $3.696 \mathrm{E}-16$ & $3.295 \mathrm{E}+01$ & $8.652 \mathrm{E}-02$ & $7.114 \mathrm{E}-01$ \\
\hline
\end{tabular}

A function of the form $y=a \times e^{(b \times x)}+c \times e^{(d \times x)}$ was used throughout the process

(see Fig. 1); therefore, the variability of the cell wall thicknesses can be assessed. An analysis of the data revealed a greater random variation of the thicknesses within a single cell than of one preferential cell wall; for example, the tangential cell wall facing toward latewood is always thicker than the one facing toward earlywood. The absolute cell wall thickness is displayed in Fig. 4. The maximum deviation of one cell wall to the other within one single cell was found to be $3.34 \mu \mathrm{m}$ in the latewood portion of growth ring 2 . The overall mean thickness difference of $0.55 \mu \mathrm{m}$ for all growth rings and cell wall orientations adds a new level of complexity to the understanding of wood formation. The thickness difference of the radial cell walls (Fig. 4 upper row) remains rather constant throughout the growth ring for all observed growth rings, whereas an increase in thickness difference toward the latewood portion is found for the tangential cell walls in growth rings 2 and 64 . However, no such increase can be found for the tangential thickness difference in growth ring 94.

Representative UV-microspectroscopic profiles for an early- and a latewood double cell wall, as well as the corresponding field scans, are given in Fig. 5. Both profiles are characterized by a more or less continuous increase toward the middle 


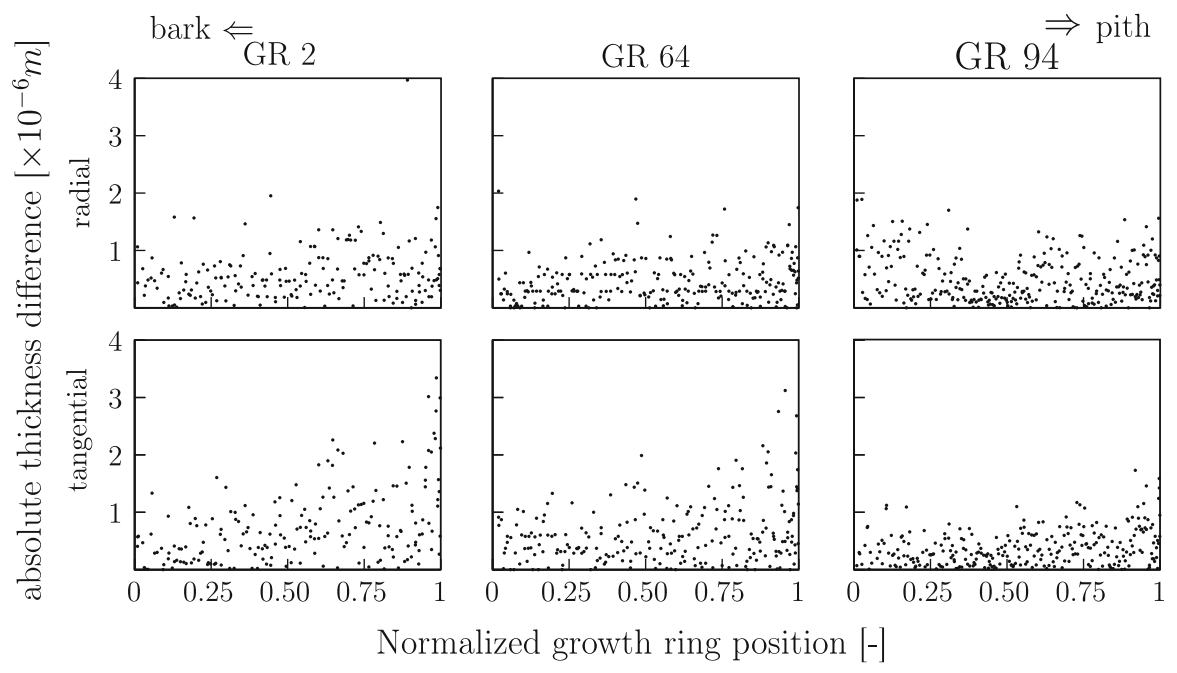

Fig. 4 Absolute intra-cell thickness variation of radial and tangential walls

lamella where they reach their maximum of about 0.4 , symmetrically from both lumen. The field scans with a resolution of $0.25 \mu \mathrm{m}^{2}$ show the maximum absorbance (light color) and thus the maximum lignin content at the cell corner regions. These regions are even more pronounced in the latewood section. Although the secondary cell wall material appears to have a more or less constant absorbance, this is not reflected in the profiles. Thus, the evaluation was carried out on rectangular fields that were not influenced by cell corner regions. The mean absorbance distribution for the three growth rings is displayed in Fig. 3 and generally shows increasing absorbance toward the end of the growth ring. Whereas for growth rings 2 and 94, the mean absorbance steadily increases toward the end of the growth ring, for growth ring 64, the absorbance first slightly decreases until a relative position of about 0.85 decreases and then increases steeply toward the end of the growth ring. Therefore, the mean absorbance for all growth rings, given in Table 1, shows a lower value for earlywood (0.13-0.22) than for latewood $(0.18-0.25)$. Note that the growth ring boundaries at positions 0 and 1 show an elevated absorbance compared to the adjacent data (Fig. 6).

\section{Discussion}

In the present study, density and MFA were measured on a whole cross section of Norway spruce using the automated SilviScan ${ }^{\circledR}$ device. Three individual growth rings were investigated closely according to their cell geometry and their topochemical lignin content, allowing direct comparison of the individual factors for each growth ring. This data, measured on the same growth rings thus minimizing the number of parameters that have to be adopted from literature, will be used in the ongoing project as input parameters for structural modeling. Furthermore, this 

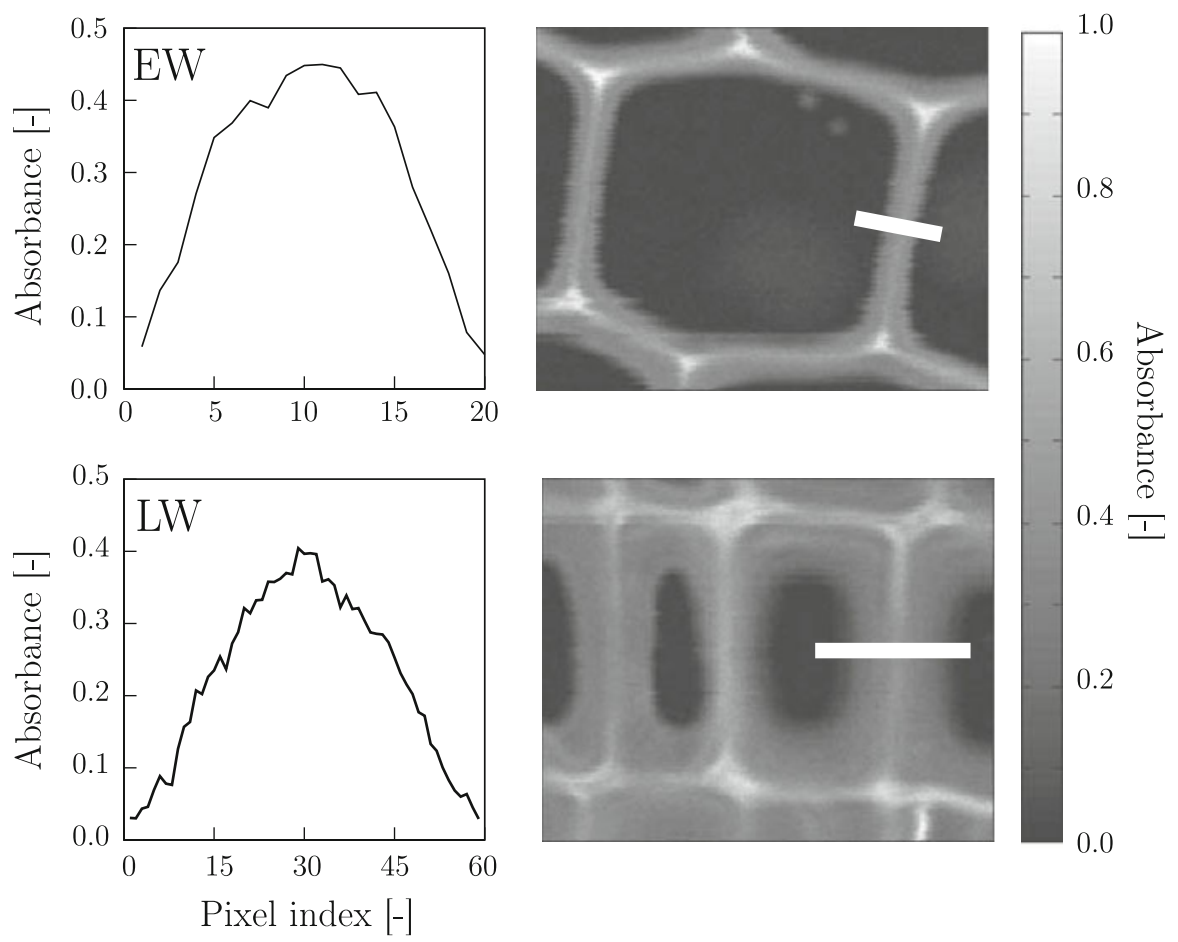

Fig. 5 Line extractions of an earlywood (EW) and latewood double cell wall (LW). Corresponding field scans taken at $280 \mathrm{~nm}$ wavelength are shown on the right

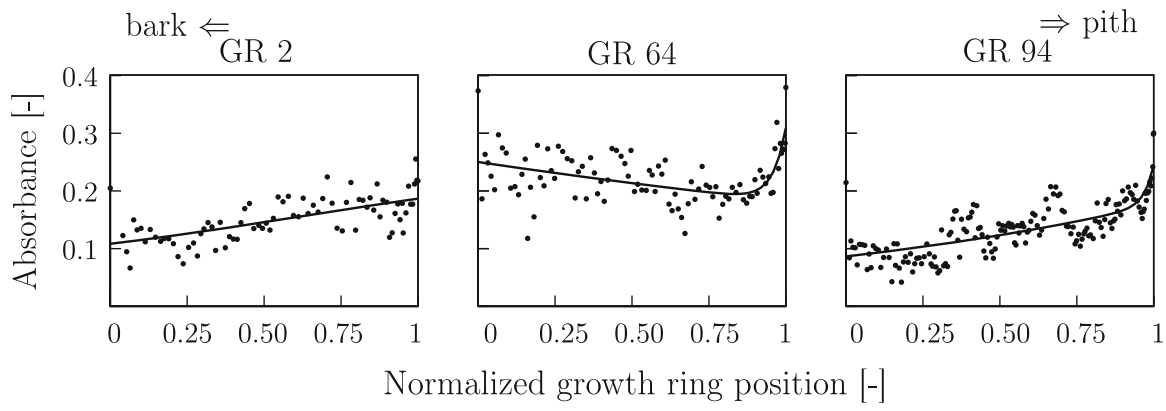

Fig. 6 Mean absorbance per cell wall area distribution over the growth ring calculated from tangential double cell walls for growth rings 2, 64 and 94. Normalized growth ring position 0 refers to earlywood boundary, 1 to latewood boundary. Please note that growth rings are numbered from bark

dataset will serve as the underlying structural data for future investigations on moisture-induced swelling and shrinkage phenomena. Due to the highly time consuming evaluation, especially of the manual measurement of the cell geometry, only three growth rings were investigated. Therefore, general trends cannot be derived, but the combination of the factors elucidates possible ways of optimization of water transport and mechanical stability by the tree. 
One such water transport optimization of the tree can be seen from the density and MFA relationship. The cell wall thickness remains almost constant throughout the growth rings within the earlywood regions and sharply increases in latewood. The opposite behavior holds valid for the lumen diameter, which is mainly responsible for the water transport, which remains constant in earlywood and decreases in latewood. This structure is clearly reflected in the radial and density profile within the growth ring. Where a relatively low density is found in the earlywood, which naturally coincides with wider lumen und thinner cell walls, the density sharply increases in the latewood. Furthermore, another optimization strategy can be seen in the MFA distribution. Whereas higher MFAs were found for all earlywood regions, it gradually reduces toward the latewood. This optimizes resistance against collapse during active capillary water transport due to suctions. On the other hand, a smaller MFA, found in latewood regions, in combination with more cell wall material (thicker cell walls) leads to a higher tensile strength.

During research on cellulose MFA in Norway spruce and its impact on mechanical properties, apart from differences induced by natural variability, the applied technique to determine the MFA plays an important role. Whereas Bergander et al. (2002) found a rapid decrease in MFA from earlywood to latewood using polarized confocal laser scanning microscopy, Lichtenegger et al. (1999) found an MFA of around $0^{\circ}$ for earlywood and a significantly higher MFA of around $20^{\circ}$ for latewood using small angle X-ray scattering. In research reported by Paakkari and Serimaa (1984), only a small difference was found between early- and latewood. Using wide angle X-ray diffraction (WAXD), Eder et al. (2009) found, in accordance with the findings of the present study, a more or less pronounced decrease in MFA from earlywood to latewood.

The literature shows relatively few studies on the lignin distribution within a growth increment. One such study was published by Fergus et al. (1969), who used point measurements to extract the absorbance values for the CPL and S2 separately. In that study, higher absorbance values, and thus higher lignin content, were found for the CPL than for S2, which remained fairly constant throughout the growth ring. $\mathrm{UV}$-spectroscopy proved to be an appropriate technique for the semi-quantitative estimation of lignin concentration in its natural state.

The data presented in the current paper represent the mean absorbance of the tangential double cell walls and therefore includes all cell wall layers. Consequently, these data account for the variability of the lignin content between the individual layers, as well as for some of the local variability within each layer. A clear distinction between the individual layers of a double cell wall was not supported by the results, since a steady increase in absorbance was found, reaching a maximum in the middle lamella, followed by a steady decrease until the next lumen where the absorbance dropped to zero. Such a lignin concentration profile across a double cell wall was also found by using Raman spectroscopy on poplar samples (Gierlinger and Schwanninger 2006). This type of profile may have resulted in part from the spatial resolution of the microscope, as the pixel size of the device $(0.25 \mu \mathrm{m})$ is slightly greater than the thickness of the middle lamella $(0.16-0.20 \mu \mathrm{m})$ reported in literature (Scott et al. 1969). Nevertheless, the results indicated that the lignin concentration in the thin-walled earlywood regions was similar to that in the latewood. Increases can 
be explained by a higher portion of highly lignified middle lamellae, which result in a higher mean absorbance in latewood. Therefore, the main optimization strategy of the tree, on a meso-scale, involves variation of the cell wall thickness rather than chemical composition (toward higher lignin content). On the other hand, the absolute lignin content increases toward the end of the growth ring due to more cell wall material, which is reflected by the significantly higher density.

The elevated absorbance at the annual ring boundaries indicates a lower radial permeability in this region and a partial radial compartmentalization of the individual growth rings. The increase in absorbance might be due to thicker and highly lignified middle lamellae that, in combination with a higher concentration of pits in the tangential cell walls found close to the growth ring borders (Laming and ter Welle 1971), may contribute to a possible strategic reaction to wounding. Owing to their faster reaction to the infiltration of air, pits in the tangential cell walls can effectively seal the adjacent growth ring in the radial direction. Furthermore, the highly lignified layer provides an extra barrier at the growth ring border. A further possible role of this feature is in the heartwood formation, where ring-wise compartmentalization is favored.

When accounting for the variation of the evaluated parameters with regard to cambial age, no clear trend can be observed. Density seems to be more influenced by growth ring width than by cambial age which is supported by Kollmann and Côté (1968). Although the latter found lower densities in juvenile wood compared to mature wood, this, however, is not reflected in the current dataset. Regarding MFA, a correlation seems to be present for growth ring width rather than for cambial age. This was also stated for mature wood by Brändström (2001), on the contrary to juvenile wood, where higher MFA was found. The latter also found an increase in cell wall thickness due to increasing latewood percentage at higher cambial ages. However, due to the limited number of evaluated growth rings and the large scatter of the data, no clear trend is visible. The same is true for the lumen diameter in the radial and tangential direction, where a possible correlation with cambial age as found by Kučera (1994) is concealed by the scatter of the data.

Although the living tree has several options to adapt its growth ring properties under varying climatic conditions (from adaption of the cell sizes, cell wall thickness and spatial arrangement of the cellulose microfibrils to the chemical composition), the investigation of this study suggests that the investigated growth rings, despite variation in width, show a standard pattern. In this pattern, one can see that earlywood is characterized by thin-walled cells with wide lumen and a higher MFA, which are optimized for water transport, and thick walled latewood cells with smaller lumen and lower MFA, which are optimized for transferring longitudinal forces. This adaptation is achieved through variations at the meso-scale, namely through cell sizes, but not through micro-scale variations in chemical composition (lignin content).

Therefore, it seems appropriate to consider this dataset, at least for this individual, as representative and thus use it for structural modeling.

Whether this determined standard cell geometry pattern is reflected in moistureinduced dimensional changes and mechanical properties on a growth ring scale, still remains to be studied. 


\section{Conclusion}

The simultaneous adaptations of cell architecture (cell wall thickness and diameter) to the requirements of water transport and mechanical strength under the influence of various environmental forces are mainly achieved by variations of the cell than by changes in the chemical composition. Therefore, the overall mean absorbance, as a measure for the absolute lignin concentration, was found to be rather constant throughout the investigated growth rings. Furthermore, the data of the present study suggest a degree of compartmentalization of the individual growth rings from one another regarding the radial water transport through a layer with elevated lignin content (mainly thicker CPL).

The cell architecture and the lignin content show no significant differences between the three observed growth rings distributed over the cross section. Therefore, the findings of this study suggest, regardless of the cambial age, that a standard pattern is applied by the tree to achieve the aforementioned tasks.

Acknowledgments The first author is grateful for the support provided by the Swiss National Science Foundation (Grant No. 125184). Parts of the current work were supported by COST Action FP0802, which funded a short-time scientific mission.

\section{References}

Badel E, Perré P (2007) The shrinkage of oak predicted from its anatomical pattern: validation of a cognitive model. Trees Struct Funct 21(1):111-120

Bergander A, Brändström J, Daniel G, Sahnen L (2002) Fibril angle variability in earlywood of Norway spruce using soft rot cavities and polarization confocal microscopy. J Wood Sci 48(4):255-263

Bodig J, Jayne BA (1993) Mechanics of wood and wood composites. Krieger Publishing Company, Malabar

Brändström J (2001) Micro- and ultrastructural aspects of Norway spruce tracheids: a review. IAWA J 22(44):333-353

Burgert I (2006) Exploring the micromechanical design of plant cell walls. Am J Bot 93(10):1391-1401

Derome D, Griffa M, Koebel M, Carmeliet J (2011a) Hysteretic swelling of wood at cellular scale probed by phase-contrast X-ray tomography. J Struct Biol 173(1):180-190

Derome D, Zillig W, Carmeliet J (2011b) Variation of measured cross-sectional cell dimensions and calculated water vapor permeability across a single growth ring of spruce wood. Wood Sci Technol 46(5):827-840

Donaldson L (2008) Microfibril angle: measurement, variation and relationships-a review. IAWA J 29(4):345-386

Eder M, Jungnikl K, Burgert I (2009) A close-up view of wood structure and properties across a growth ring of Norway spruce Picea abies [L] Karst. Trees-Struct Funct 23(1):79-84

Evans R (1994) Rapid measurement of the transverse dimensions of tracheids in radial wood sections from Pinus radiata. Holzforschung 48(2):168-172

Evans R, Hughes M, Menz D (1999) Microfibril angle variation by scanning X-ray diffractometry. Appita J 52(5):363-367

Fengel D, Stoll M (1973) Über die Veränderungen des Zellquerschnitts, der Dicke der Zellwand und der Wandschichten von Fichtenholz-Tracheiden innerhalb eines Jahrringes. Holzforschung. Int J Biol Chem Phys Technol Wood 27. doi:10.1515/hfsg.1973.27.1.1

Fengel D, Wegener G (1984) Wood chemistry, ultrastructure, reactions. Walter de Gruyter, Berlin

Fergus BJ, Procter AR, Scott JAN, Goring DAI (1969) The distribution of lignin in sprucewood as determined by ultraviolet microscopy. Wood Sci Technol 3(2):117-138

Fritts HC (1976) Tree rings and climate. Academic Press, London 
Fukazawa K, Imagawa H (1981) Quantitative analysis of lignin using an UV microscopic image analyser. variation within one growth increment. Wood Sci Technol 15(1):45-55

Gierlinger N, Schwanninger M (2006) Chemical imaging of poplar wood cell walls by confocal Raman microscopy. Plant Physiol 140(4):1246-1254

Gindl W (2001a) Cell-wall lignin content related to tracheid dimensions in drought-sensitive Austrian pine (Pinus Nigra). IAWA J 22(2):113-120

Gindl W (2001b) The effect of varying latewood proportion on the radial distribution of lignin content in a pine stem. Holzforschung 55:455-458

Gindl W, Grabner M (2000) Characteristics of spruce [Picea abies (L.) Karst] latewood formed under abnormally low temperatures. Holzforschung 54:9-11

Gindl W, Grabner M, Wimmer R (2000) The influence of temperature on latewood lignin content in treeline Norway spruce compared with maximum density and ring width. Trees Struct Funct 14(7):409-414

Gindl W, Grabner M, Wimmer R (2001) Effects of altitude on tracheid differentiation and lignification of Norway Spruce. Can J Bot 79:815-821

Gindl W, Gupta HS, Schoberl T, Lichtenegger HC, Fratzl P (2004) Mechanical properties of spruce wood cell walls by nanoindentation. Appl Phys Mater Sci Process 79(8):2069-2073

Hofstetter K, Hellmich C, Eberhardsteiner J (2005) Development and experimental validation of a continuum micromechanics model for the elasticity of wood. Eur J Mech A Solids 24(6):1030-1053

Jenkins PA (1975) Influence of temperature change on wood formation in Pinus radiata grown in controlled environments. NZ J Bot 13(4):579-591

Kienast F, Schweingruber FH, Bräker OU, Schär E (1987) Tree-ring studies on conifers along ecological gradients and the potential of single-year analyses. Can J For Res 17(7):683-696

Kollmann FF, Côté WA (1968) Principles of wood science and technology: Part I solid wood. Springer, Berlin

Kučera B (1994) A hypothesis relating current annual height increment to Juvenile wood formation in Norway spruce. Wood Fiber Sci 26(1):152-167

Laming PB, ter Welle BJH (1971) Anomalous tangential pitting in Picea abies (L.) Karst. (European Spruce). IAWA Bull, pp 3-10

Lassen L, Okkonen E (1969) Effect of rainfall and elevation on specific gravity of coast Douglas-fir. Wood Fiber Sci 1(3):227-235

Lichtenegger H, Reiterer A, Stanzl-Tschegg S, Fratzl P (1999) Variation of cellulose microfibril angles in softwoods and hardwoods - a possible strategy of mechanical optimization. J Struct Biol 128:257-269

Niemz P (1993) Physik des Holzes und der Holzwerkstoffe. DRW, Leinfelden-Echterdingen

Oleksyn J, Fritts HC (1991) Influence of climatic factors upon tree rings of Larix decidua and L. decidua $\times$ L. kaempferi from Pulawy, Poland. Trees Struct Funct 5(2):75-82

Paakkari T, Serimaa R (1984) A study of the structure of wood cells by X-ray diffraction. Wood Sci Technol 18(2):79-85

Perré P, Badel É (2003) Predicting of oak wood properties using X-ray inspection: representation, homogenisation and localisation. Part II: computation of macroscopic properties and microscopic stress fields. Ann For Sci 60(3):247-257

Qing H, Mishnaevsky L (2009) 3D hierarchical computational model of wood as a cellular material with fibril reinforced, heterogeneous multiple layers. Mech Mater 41(9):1034-1049

Salmén L (2004) Micromechanical understanding of the cell-wall structure. CR Biol 327(9-10):873-880

Scott JAN, Procter AR, Fergus BJ, Goring DAI (1969) The application of ultraviolet microscopy to the distribution of lignin in wood. Description and validity of the technique. Wood Sci Technol 3(1):73-92

Splechtna BE, Dobrys J, Klinka K (2000) Tree-ring characteristics of subalpine fir (Abies lasiocarpa (Hook.) Nutt.) in relation to elevation and climatic fluctuations. Ann For Sci 57(2):89-100

Wagenführ R (2000) Holzatlas. Fachbuchverlag, Leipzig

Wilson JW, Wellwood RW (1965) Intra-increment chemical properties of certain western Canadian coniferous species. In: Coté WA (ed) Cellular ultrastructure of woody plants. Syracuse University Press, Syracuse, pp 551-559

Wimmer R, Lucas BN (1997) Comparing mechanical properties of secondary wall and cell corner middle lamella in Spruce wood. IAWA J 18(1):77-88

Wimmer R, Lucas BN, Oliver WC, Tsui TY (1997) Longitudinal hardness and Young's modulus of spruce tracheid secondary walls using nanoindentation technique. Wood Sci Technol 31(2):131-141

Zobel BJ, Van Buijtenen JP (1989) Wood variation-its causes and control. Springer series in wood science. Springer, Berlin 